\title{
THE EFFECTIVENESS OF COMPUTER-BASED GAMES AS A LEARNING MEDIA ON THE IUPAC NAME OF INORGANIC COMPOUNDS
}

\author{
Rusly Hidayah, Nuril Lailiyah Iswahyuni, Rista Ajeng Mitasari \\ Universitas Negeri Surabaya
}

\begin{abstract}
Learning media made must meet the eligibility criteria, one of which is effectiveness. The research was aimed to examine the effectiveness of computer-based games as a learning media on the nomenclature of an inorganic compound topic. This research used Plomp design research, which consists of three phases: preliminary phase, design prototype phase, and assessment phase. This research trial was 28 students in X grade at Senior High School 1 Puri Mojokerto used one group pretest and posttest design. The game's effectiveness $\mathrm{s}$ is based on the n-gain score from the pretest and posttest results, which data is normalized by Kolmogorov-Smirnov non-parametric test. The results of the $\mathrm{n}$-gain calculation are $71.4 \%$ of students in one class have a moderate $n$ gain category, $21.42 \%$ of students have a high n-gain category, and $7.18 \%$ of students have low ngain criteria. Thus, it can be concluded that computer-based games are effective learning media.
\end{abstract}

Keywords: Learning Media, game, the nomenclature of inorganic compounds.

\section{INTRODUCTION}

Education in Indonesia is continuously developing now. The government continues to evaluate and update the curriculum. One of the reasons is that education in Indonesia has not competed with the outside world. The government's goal to make updates is that in line with increasingly rapid technological developments, it is also necessary to update learning so that learning develops by the times. The government hopes that innovation and curriculum renewal can improve the quality of education and the quality of resources in Indonesia, which is deteriorating. Curriculum renewal can be seen clearly when the 2013 Curriculum was launched, replacing the 2006 KTSP curriculum. Whereas learning should be carried out based on fun, challenging activities and motivating students to participate actively (Permendikbud, 2014).

Chemistry is the study of reactions, structure, properties, and matter changes. Concepts in chemistry are generally abstract and complex, which use scientific reasoning. Students assume that chemistry subjects are difficult, and the material is generally abstract and a lot of rote, so they find it difficult to understand the concept. One of the chemicals with a lot of memorization is the material nomenclature of compounds. Nomenclature of compounds is a material that contains the rules for naming chemical compounds. The characteristics of this material are memorizing compound names and compound formulas. There are two basic naming compounds, namely trivial and IUPAC. The IUPAC name is the name of the compound according to its chemical formula (international agreement), While the trivial name is the name of the compound based on common names. In understanding the concept of nomenclature of chemical compounds, students must memorize compounds, compound formulas and understand the concept of

\footnotetext{
${ }^{*}$ Corresponding author: Universitas Negeri Surabaya, Indonesia. Email: Habiddin_wuni@um.ac.id
} 
compound naming rules. Therefore, before studying this material, students must know about element names, symbols, charges, oxidation numbers. These prerequisites need to be known and understood so that students do not experience difficulties understanding the concept of nomenclature of chemical compounds. However, students generally have difficulty memorizing chemical compounds, which are quite a lot. In addition, monotonous learning tends to make students easily bored, so that interest in studying chemistry is low.

Based on the results of the questionnaire distribution at SMAN 1 Puri Mojokerto which stated that $64 \%$ of students stated that learning chemistry was difficult. In addition, $46 \%$ of students stated that Compound Nomenclature is a difficult subject compared to Chemical Bonds (26\%), SPU (18\%) and Atomic Structure (4\%). Students stated that the most difficult Compound Nomenclature sub-material was Polyatomic Compounds with 41\%. In addition, 64\% of students stated that learning tends to use the lecture method, and teachers do not use learning media. As many as $76 \%$ of students want the learning process to be interspersed with games, and $88 \%$ of students expressed interest if chemistry lessons are taught with game media.

The development of this technology greatly influences students' learning process. The use of technology for students gives birth to two types of students, namely students who rely on technology for their academic needs and just for fun; for example, students prefer to use technology to play games so that they become addicted to games. Students prefer to play games than have to study. Of course, this can cause learning activities to be disrupted and cause students difficulty learning. Moreover, the lesson is difficult. It is necessary to develop educational games called Game-Based Learning (GBL). With this Game-Based Learning, it is hoped that students will play and learn from what is played so that Game-Based Learning can be an interesting solution for students.(Maulidina, Susilaningsih, \& Abidin, 2018)

Games can be used as learning media because games can make students active in learning. Games as learning media involve students in the process of experience and at the same time live the challenges, get inspired, are encouraged to be creative in all activities in playing games. In addition, the use of games in learning can increase interest in learning to improve learning outcomes(Dananjaya, 2017). In addition, students get a higher score with the game than explained by the teacher during the final evaluation. Games can represent a more fun and interesting approach with motivation and better learning outcomes. Another study states that computer-based games in learning are a good alternative to laboratory assignments and memorization. Students can develop interest through (Manero, 2015) competitions and coding challenges in games. The use of media in games can improve the development of students' cognition and interest in learning. One effort to minimize this problem is to use learning media in the Nom Chemy game in the IUPAC nomenclature material for inorganic compounds to increase interest in learning about the material (Chandel, 2015).

\section{METHOD}

The type of research used is development research with the Plomp method, consisting of 3 stages: preliminary, prototype, and assessment (Plomp, 2013). The preliminary stage includes several curriculum analyses, teacher analysis, student analysis, and material analysis. This analysis was conducted pre-research at SMA Negeri 1 Puri Mojokerto by conducting questionnaires and teacher interviews prototyping stage includes designing games as learning media and making instruments. Game design produces games as learning media (prototype) with several drafts, namely storyboards, flowcharts and game guide books. The instruments needed in the research include the pretest and posttest instruments. 
In the assessment stage there is an assessment of the game based on the increase in the scores of the pretest and posttest instruments using the One-Group Pre-test-Post test Design (Sugiyono, 2017) as in Figure 1.

\begin{tabular}{|lllll|}
\hline Pre test & & Treatment & & Post test \\
$\mathrm{O} 1$ & $\rightarrow$ & $\mathrm{X}$ & $\rightarrow$ & $\mathrm{O}_{2}$ \\
\hline
\end{tabular}

Figure 1 One-Group Pre-test-Post-test Design

Notes:

$\mathrm{O}_{1}$ : The initial test is in the form of a written test to determine the initial value of the Inorganic Compound Nomenclature material

$\mathrm{X}$ : Treatment using games

$\mathrm{O}_{2}$ : The final test is in the form of a written test to determine the final score of the Inorganic Compound Nomenclature material.

Effectiveness is based on increasing pretest and posttest scores as assessed by the n-gain score. The Kolmogorov-Smirnov test normalized the pretest and posttest scores in SPSS. Then the $\mathrm{n}$-gain score is calculated using the formula:

$$
\mathrm{N} \text {-gain }=\frac{S_{\text {post }}-S_{\text {pre }}}{S_{\text {max }}-S_{\text {pre }}}
$$

Then, the n-gain results are adjusted according to the n-gain category.

Table 1. n-gain category score.

\begin{tabular}{ll}
\hline Score & Category \\
\hline $\mathbf{g} \geq \mathbf{0 . 7 0}$ & High \\
$\mathbf{0 . 7}>\mathbf{g} \geq \mathbf{0 . 3}$ & Medium \\
$\mathbf{g}<\mathbf{0 . 3 0}$ & Low \\
\hline
\end{tabular}

The game is effective if the n-gain score is $\geq 0.3$ in the medium category (Hake, 1998).

\section{RESULTS AND DISCUSSION}

The results obtained from research on the effectiveness of computer-based games as learning media for IUPAC nomenclature of inorganic compounds are as follows. The preliminary stage includes several analyses, namely curriculum, analysis, teacher analysis, student analysis, and material analysis. This analysis was conducted when conducting preliminary research at SMA Negeri 1 Puri Mojokerto by conducting questionnaires and teacher interviews. In this school, the revised edition of the 2013 curriculum is used. Chemistry teachers have never used learning media in games in this school. Students have never been taught to use games on multiple nomenclature topics and want to learn to use games or other innovative learning media. 
The next stage is making a prototype which includes game design and instrument preparation. The game design produces games as learning media (prototype) with several drafts, namely storyboards, flowcharts and game guide books. The instruments needed in this research include pretest and posttest sheets. The name of this game is Nom Chemy (Nomenclature of Chemical Compound). The game's display is shown in Figure 2, and the design of the game manual is shown in Figure 3. The game uses bilingual language (Indonesian and English versions)
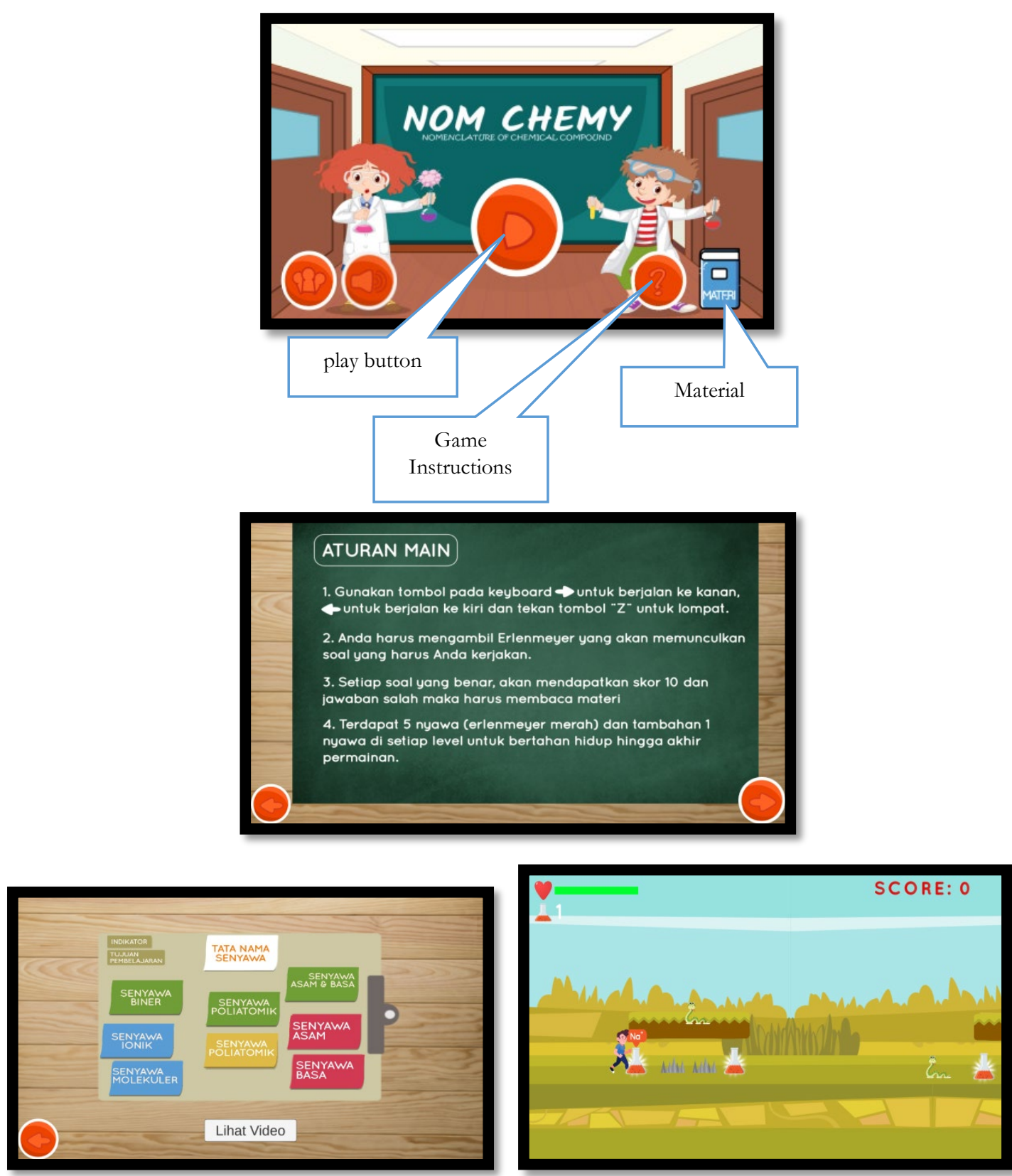

Figure 2. The appearance of the Nom Chemy Game 


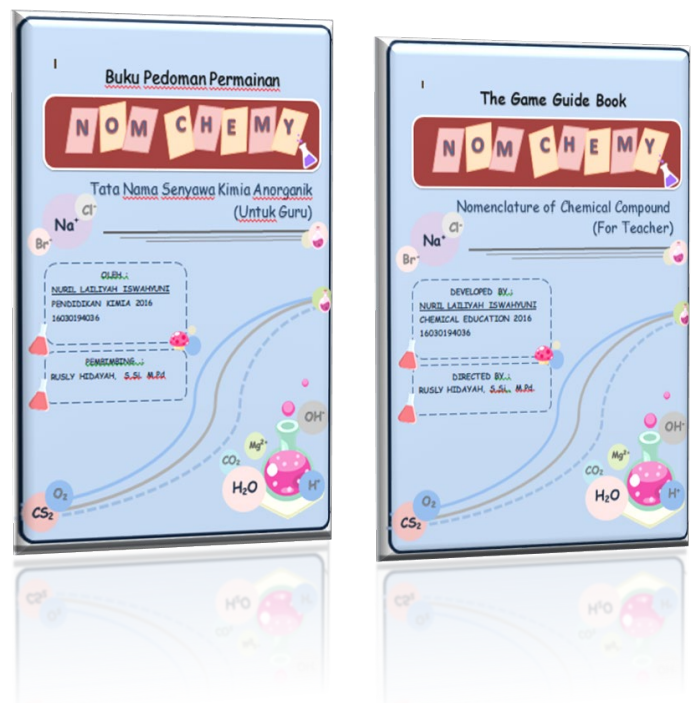

Figure 3. Game playbook design.

At the assessment stage, an assessment is carried out. The instruments are a pretest sheet and a posttest sheet whose results are calculated using the n-gain formula. Normality test using SPSS 22 application with non-parametric Kolmogorov-Smirnov test. Kolmogorov-Smirnov test results Sig. (2-tailed) pretest $=0.141$ and posttest $=0.079$. This indicates that the data has a normal distribution because the significance value of both data is more than 0.05 . After that, the data is calculated for the n-gain score and then adjusted to the n-gain criteria. In class X IPA 2 with 28 students, the results of the n-gain scores are shown in Table 2.

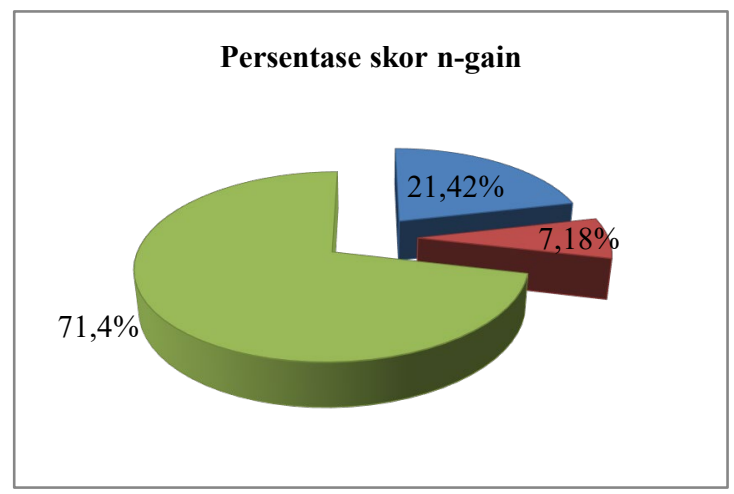

Figure 4. Results Percentage Score n-gain.

Based on Figure $5,71.4 \%$ of students have an n-gain value in the range of $0.7>g \geq 0.3$ so that it is included in the medium criteria, $21.42 \%$ of students have an $n$-gain value with a range of $g \geq 0.70$ with high criteria and $7.18 \%$ of students have an n-gain score with a range of $g<0.30$ with low criteria. That is, $92.82 \%$ of students have medium and high criteria, so that it can be said that the game is an effective learning media. Learning media can be more effective in helping students improve understanding, present attractive and reliable presentations and facilitate interpretation and condense information (Arsyad, 2013). Following Lutfi and Hidayah, games used as learning media can improve students' learning outcomes (Lutfi \& Hidayah, 2017). Besides 
that, a Computer-based compound naming game effectively increases students earning scores compared to conventional learning (Nunes, et al., 2017). One of the advantages of games as learning media is that games can allow the implementation of concepts or characters in these situations in society (Sadiman, 2014).

Effectiveness is also supported by students' interest in the Nom Chemy game. Based on the results of the response questionnaire, it is known that many students are interested in the Nom Chemy game. This is supported by the activities of students while using the game. Students use the game to the last level even though they have failed. Because the game contains questions that students must answer, there is an interest in studying the material in the game, namely Compound Nomenclature, to answer questions in the game. This learning interest then affects learning outcomes; increasing learning outcomes becomes more optimal if there is interest (Sardiman, 2001). In addition, a game can provide natural motivation, part of a good strategy and can build concepts (Brensell \& Hansen, 2010).

Playing is fun and can give a new learning experience if it can be used properly. By using games as a learning media, you will get new learning experiences that affect the level of cognition of students. Piaget stated that The experience gained by students in building knowledge must harmonize between assimilation and accommodation. By playing, assimilation is obtained when there is feedback when students answer questions correctly. With direct feedback that the student's answer is correct, it can be seen that students have the same knowledge as the previous knowledge. Thus, the process of accepting new experiences by playing is acceptable. While the accommodation obtained is when students answer the wrong question while playing, the student will have to read the explanation expected in the next question. The student does not answer incorrectly. With a situation when playing requiring students to read explanations, this situation can harmonize the previously obtained information. So that students are expected not to answer the question wrong(Slavin, 2011)

Play can be a means of learning (Slavin, 2011). According to Vygotsky's theory, the play has an important role because it provides opportunities for students to develop ways of thinking that are above the current level of functioning. In addition, playing can improve cognition in abstract thinking to increase ZPD (Zone of Proximal Development). When children play, they will be controlled by this self-control, which can be called a stimulus that can increase ZPD. Therefore.

From explaining these theories, learning media is a medium that can help students deliver information to increase students' understanding of the material. This understanding of students is evidenced by increased student learning outcomes, from before the use of the media and after using the media. However, in Table 2 presented, some students have a low increase in learning outcomes or an $n$-gain score $<0.3$. There are $7.18 \%$ of students with an $n$-gain score with a low criterion of 0.25 . The low n-gain score occurs because students do not understand the rules of the game, do not understand the questions and material in the game as if students want to play and finish the game immediately. Besides that, There are student activities that are not relevant, for example, distractions when using games that cause students to be less focused in answering questions such as asking friends, making noise in the class by making sounds of victory or defeat and cheating on their friends' answers when using games. So that students do not maximize their ability to answer questions and understand explanations in the game. In addition to students' technical problems, student learning styles also affect student learning outcomes. Every student has a different learning style. Students whose learning style uses visual or kinesthetic may be suitable for this learning media, but it is not necessarily suitable for students with an auditive learning style. 
In testing students' ability, there are indicators of competency achievement that must be achieved in the pretest and posttest questions. One of them is the selection of media must be adjusted to the learning objectives or competencies to be achieved (Munadi, 2013). Learning media must adapt to the designed learning objectives that refer to students' competence. And then, This competence is tested on the pretest and posttest questions.

There are three indicators of competency achievement in KD 3.9, namely; 3.9.1 Apply the rules for naming chemical compounds formed from ionic compounds according to IUPAC rules; 3.9.2 Applying rules for naming chemical compounds and formulas for compounds formed from molecular compounds based on IUPAC rules; and 3.9.3 Applying the rules for naming compounds and formulas for compounds formed from polyatomic acids and bases based on IUPAC rules. The increase in $\mathrm{n}$-gain is shown in Table 2.

Table 2. The results of the n-gain score are based on learning indicators.

\begin{tabular}{lcccc}
\hline \multicolumn{1}{c}{ Indicator } & $\begin{array}{c}\text { Average } \\
\text { pretest } \\
\text { score }\end{array}$ & $\begin{array}{c}\text { Average } \\
\text { posttest } \\
\text { score }\end{array}$ & N-gain & Criteria \\
\hline $\begin{array}{l}\text { 3.9.1 Apply the rules for naming chemical } \\
\text { compounds formed from ionic } \\
\text { compounds according to IUPAC rules }\end{array}$ & 41.07 & 80.35 & 0.66 & Medium \\
\hline $\begin{array}{l}\text { 3.9.2 Apply the rules for naming chemical } \\
\text { compounds and formulas compounds } \\
\text { that formed from molecular compounds } \\
\text { based on IUPAC rules }\end{array}$ & 50 & 82.14 & 0.64 & Medium \\
\hline $\begin{array}{l}\text { 3.9.3 Apply the rules for naming } \\
\text { compounds and formulas compounds } \\
\text { that formed from polyatomic acids and } \\
\text { bases based on IUPAC rules }\end{array}$ & 56.42 & 80 & 0.54 & Medium \\
\end{tabular}

Based on Table 2, three indicators have different n-gain results. In the game, the first indicator is at level 1, and indicator two is at level 2 and indicator three is at level 3 . The first indicator gets an n-gain value of 0.66 with medium criteria. This indicator contains two questions about naming ionic compounds. In the pretest, from these two questions, on average, students answered one question incorrectly, and only two students could answer correctly from these two questions, even some students answered all of them incorrectly.

Meanwhile, in the posttest, the average student answered all correctly, and some still answered one or even all wrong. The second indicator has three questions about naming molecular compounds that get an n-gain value of 0.64 with medium criteria. The average student answered two incorrectly out of three questions in the pretest questions. While in the posttest, the average student answered correctly, although some answered with one wrong answer. Furthermore, there are five questions for naming polyatomic compounds, acids and bases with an $n$-gain value of 0.54 with medium criteria in the third indicator. Of the three indicators, this indicator has the lowest $\mathrm{n}$-gain. This is caused by the number of more questions and contains material about polyatomic compounds, wherein the average student has difficulty with this material. The pretest results show that this indicator has the highest score of the other two indicators because this indicator has a larger number of questions. On average, students answered two questions incorrectly, and some answered three questions incorrectly, even four 
questions. While in the posttest, on average, students answered one question incorrectly, and only one student answered all correctly. Of these three indicators, there are questions with difficult criteria, namely indicators two and three. In indicator two, students must name the form of a compound molecule, while in indicator three, students must name compounds from phenomena in everyday life. On average, on these two questions, students answered incorrectly on the pretest and the posttest. There were still some who answered incorrectly. This is following the increase in n-gain, which is lower than the first indicator. There is an increase in scores before and after using game media when viewed from achievement indicators (Rahmanah \& Hidayah, 2019). From these three indicators, it can be concluded that the n-gain values from the highest to the lowest are indicator 1 , indicator 2 , and indicator 3 .

\section{CONCLUSION}

This game is effective as a learning media because $71.4 \%$ of students get medium n-gain and $21.42 \%$ get high n-gain. This game has been tested on students, and students are interested in this game. This computer-based game technology is in accordance with the level of cognition of students. This game uses a three-stage method that produces an analysis of teachers, schools, students, and subject matter at the preliminary stage. The game was named "Nom Chemy" at the prototyping stage, and the game manual was designed for teachers. At the assessment stage, the game is effective as a learning media based on the value of n-gain, and students are interested in participating in the learning. Based on the research conducted, there are suggestions for further development research; the game is in .exe format with loading RAR data. So the laptop/computer must have the RAR application and cannot use ZIP or other applications, so some laptops cannot open this game application.

\section{REFERENCES}

Arsyad, A. (2013). Media Pembelajaran. Jakarta: PT RajaGrafindo Persada.

Brensell, \& Hansen, C. (2010). Designing an Educational Game: Design Principles From a Holistic Perspective. International Journal of Learning, 17 (10), 279-920.

Chandel, P. D. (2015). Digital Game-Based Learning in Computer Science Education. CPUH Res. J1(2), 33-37.

Dananjaya, U. (2017). Media Pembelajaran Aktif cetakan ke-4. Bandung: Nuansa Cendekia.

Hake, R. R. (1998). Interactive Engagement Versus Traditional Methods: A Six Thousand Student Survey of Mechanics Test Data for Introductory Physics Courses. 66.

Lutfi, A., \& Hidayah, R. (2017). Activating Student to Learn Chemistry using Chemmy Card 6-1 Game as an Instructional Medium in IUPAC Nomenclature of Inorganic Compound

Manero, B. e. (2015). Can Educational Video Games Increase High School Students' Interest In Theatre? Computers and Education Journal, 182-191.

Maulidina, M. A., Susilaningsih, \& Abidin, Z. (2018). Pengembangan Game Based Learning Berbasis Pendekatan Saintifik Pada Siswa Kelas IV Sekolah Dasar. Jurnal Teknologi Pendidikan, Fakultas Ilmu Pendidikan, Universitas Negeri Malang, 113-

Nunes, Lima, Miranda, Junior, Alexandre, Carlos, et al. (2017). Nomenclature Bets: An Innovative Computer-Based Game To Aid Students in the Study of Nomenclature of Organic Compounds. Journal of Chemical Education (95), 899-902.

Permendikbud. (2014). Peraturan Pemerintah No. 32 Tabun 2013 tentang Standar Kompetensi Lulusan dan Standar Isi. Jakarta: Permendikbud.

Plomp, T. (2013). Educational Design Research: An Introduction. Enschede: SLO Netherland Institute for Curriculum Development.

Riduwan. (2016). Skala Pengukuran Variabel-V ariabel Penelitian. Bandung: Alfabeta. 
Sadiman. (2014). Media Pendidikan. Jakarta: PT Raja Grafindo Persada.

Sardiman. (2001). Interaksi dan Motivasi Belajar Mengajar. Jakarta: PT Raja Grafindo Persada.

Slameto. (2010). Belajar dan Fak.tor-Faktor Yang Mempengarubinya. . Jakarta: Rineka cipta.

Slavin, R. E. (2011). Psikologi Pendidikan : Teori dan Praktek Edisi Sembilan. Jakarta: P'T Indeks.

Sugiyono. (2017). Metode Penelitian Pendidikan Pendekatan Kuantitatif, Kualitatif, dan R\&D. Bandung: Alfabeta.

Supendi, Pepen, \& Nurhidayat. (2007). Fun Game. Jakarta: Penerba Swadaya. 